\title{
Water-Soluble $\mathrm{Mo}_{3} \mathrm{~S}_{4}$ Clusters Bearing Hydroxypropyl Diphosphine Ligands: Synthesis, Crystal Structure, Aqueous Speciation, and Kinetics of Substitution Reactions
}

\author{
Manuel G. Basallote, ${ }^{\dagger \dagger}$ M. Jesús Fernández-Trujillo, ${ }^{\dagger}$ Jose Ángel Pino-Chamorro, ${ }^{\dagger}$ Tomás F. Beltrán, ${ }^{\ddagger}$ \\ Carolina Corao, ${ }^{\ddagger}{ }^{\ddagger}$ Rosa Llusar, ${ }^{*} \neq$ Maxim Sokolov, ${ }^{\ddagger}, \|$ and Cristian Vicent ${ }^{\perp}$ \\ ${ }^{\dagger}$ Departamento de Ciencia de los Materiales e Ingeniería Metalúrgica y Química Inorgánica, Facultad de Ciencias, Universidad de \\ Cádiz, Apartado 40, Puerto Real, 11510 Cádiz, Spain \\ ${ }^{\ddagger}$ Departament de Química Física i Analítica, Universitat Jaume I, Av. Sos Baynat s/n, 12071 Castelló, Spain \\ ${ }^{\S}$ Laboratorio de Catálisis y Metales de Transición, Facultad de Ciencias y Tecnología, Departamento de Química, Universidad de \\ Carabobo, Valencia, Edo, Carabobo, Apartado Postal 3336, Venezuela \\ "Nikolaev Institute of Inorganic Chemistry, SB RAS, Prospekt Lavrentyeva 3, 630090 Novosibirsk, Russia \\ ${ }^{\perp}$ Serveis Central d’Instrumentació Científica, Universitat Jaume I, Av. Sos Baynat s/n, 12071 Castelló, Spain
}

Supporting Information

ABSTRACT: The $\left[\mathrm{Mo}_{3} \mathrm{~S}_{4} \mathrm{Cl}_{3}(\text { dhprpe })_{3}\right]^{+}\left(\mathbf{1}^{+}\right)$cluster cation has been prepared by reaction between $\mathrm{Mo}_{3} \mathrm{~S}_{4} \mathrm{Cl}_{4}\left(\mathrm{PPh}_{3}\right)_{3}$ (solvent) ${ }_{2}$ and the watersoluble 1,2-bis(bis(hydroxypropyl)phosphino)ethane (dhprpe, L) ligand. The crystal structure of $[1]_{2}\left[\mathrm{Mo}_{6} \mathrm{Cl}_{14}\right]$ has been determined by X-ray diffraction methods and shows the typical incomplete cuboidal structure with a capping and three bridging sulfides. The octahedral coordination around each metal center is completed with a chlorine and two phosphorus atoms of the diphosphine ligand. Depending on the $\mathrm{pH}$, the hydroxo group of the functionalized diphosphine can substitute the chloride ligands and coordinate to the cluster core to give new clusters with tridentate deprotonated dhprpe ligands of formula $\left[\mathrm{Mo}_{3} \mathrm{~S}_{4}(\text { dhprpe- } \mathrm{H})_{3}\right]^{+}\left(\mathbf{2}^{+}\right)$. A detailed study based on stopped-flow, ${ }^{31} \mathrm{P}\left\{{ }^{1} \mathrm{H}\right\}$ NMR, and electrospray ionization mass spectrometry techniques has been carried out to understand

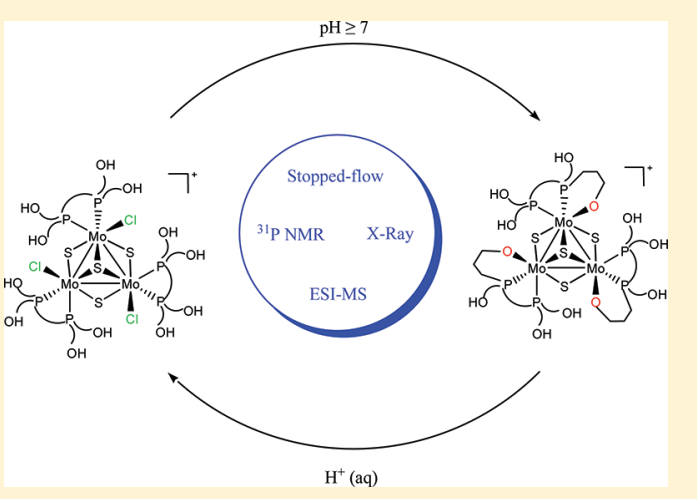
the behavior of acid-base equilibria and the kinetics of interconversion between the $\mathbf{1}^{+}$and the $\mathbf{2}^{+}$forms. Both conversion of $\mathbf{1}^{+}$ to $2^{+}$and its reverse process occur in a single kinetic step, so that reactions proceed at the three metal centers with statistically controlled kinetics. The values of the rate constants under different conditions are used to discuss on the mechanisms of opening and closing of the chelate rings with coordination or dissociation of chloride.

\section{INTRODUCTION}

The search for stable water-soluble transition metal complexes for catalytic and biomedical purposes is one of the challenges of modern coordination chemistry. ${ }^{1-5}$ Among the various ligand families which can furnish hydrophilic ligands leading to watersoluble complexes, phosphines functionalized with hydroxo or sulfonate groups have been the ligands of choice. ${ }^{4,6,7}$ The most studied are complexes with tris(hydroxymethyl)phosphine $\left(\mathrm{P}\left(\mathrm{CH}_{2} \mathrm{OH}\right)_{3}\right)$ and hydroxyalkyl diphosphines. ${ }^{8-18}$ The coordination chemistry of both early and late transition metals with these phosphines has been explored to some extent, and in some cases, the activity of the complexes in biphasic catalytic reactions has been detected. ${ }^{4}$ On the other hand, despite the well-known fact that cluster complexes of transition metals are often stabilized by phosphine ligands, water-soluble complexes of clusters with hydroxylated phosphines are almost unknown. There is, in fact, a vast family of chalcogenide cluster complexes, based on the incomplete cuboidal $\mathrm{M}_{3} \mathrm{Q}_{4}$ cores $(\mathrm{M}$
$=\mathrm{Mo}, \mathrm{W} ; \mathrm{Q}=\mathrm{S}, \mathrm{Se})$, which for a long time has been attracting a considerable amount of interest due to the unique possibility of cluster modification and to the valuable properties resulting thereof. A variety of heterometals (more than 20) can be readily incorporated into the $\mathrm{M}_{3} \mathrm{Q}_{4}$ core to give full-fledged cuboidal cluster complexes $\mathrm{M}_{3} \mathrm{M}^{\prime} \mathrm{Q}_{4}$ with unique reactivity patterns at the $\mathrm{M}^{\prime}$ site. ${ }^{19-21}$ Catalytic activity has been reported for $\mathrm{Mo}_{3} \mathrm{M}^{\prime} \mathrm{S}_{4}\left(\mathrm{M}^{\prime}=\mathrm{Cu}, \mathrm{Ni}, \mathrm{Pd}, \mathrm{Ru}\right)$ clusters. ${ }^{22-27}$ Water-soluble $\mathrm{W}_{3} \mathrm{~S}_{4}$ derivatives are potential candidates for new-generation $\mathrm{X}$ ray contrast agents. ${ }^{28}$ However, until very recently, watersoluble derivatives of the incomplete cuboidal clusters and their heterometal derivatives were restricted to the aqua complexes $\left[\mathrm{M}_{3} \mathrm{Q}_{4}\left(\mathrm{H}_{2} \mathrm{O}\right)_{9}\right]^{4+}$ and $\left[\mathrm{M}_{3} \mathrm{M}^{\prime} \mathrm{Q}_{4}\left(\mathrm{H}_{2} \mathrm{O}\right)_{10}\right]^{4+}$ (stable only in highly acidic media at $\mathrm{pH}$ around 0$),{ }^{19}$ to oxalates $\left[\mathrm{M}_{3} \mathrm{Q}_{4}\left(\mathrm{C}_{2} \mathrm{O}_{4}\right)_{3}\left(\mathrm{H}_{2} \mathrm{O}\right)_{3}\right]^{2-29}$ and to complexes with amino-

Received: March 8, 2012

Published: June 5, 2012 
polycarboxylate ligands, chiefly with nta (nitrylotriacetate), whose preparation also requires very strict $\mathrm{pH}$ control. ${ }^{30}$ Our recent work has added water-soluble 1,2-bis(bis(hydroxymethyl)phosphino)ethane (dhmpe) to this list and allowed isolation and structural characterization of $\left[\mathrm{Mo}_{3} \mathrm{~S}_{4} \mathrm{Cl}_{3}(\mathrm{dhmpe})_{3}\right] \mathrm{Cl}^{31}$ Speciation studies have identified a complicated solution behavior of the cluster complex with $\left[\mathrm{Mo}_{3} \mathrm{~S}_{4}(\text { dhmpe })(\text { dhmpe-H })_{2}\right]^{2+}$ as the dominant species in water. Formation of the latter is quite remarkable since it requires closure of two four-membered $\mathrm{Mo}-\mathrm{O}-\mathrm{C}-\mathrm{P}$ rings. In the present work, we report our studies on coordination of a higher homologue of dhmpe, namely, the 1,2-bis(bis(hydroxypropyl)phosphino)ethane, dhprpe. An increase of the alkyl chain from methyl to propyl dramatically changes the solubility of the $\mathrm{Mo}_{3} \mathrm{~S}_{4}$ cluster in water, which increases by a factor of 100 . Aqueous speciation studies at different $\mathrm{pHs}$ have been undertaken aimed to understand such differences. The high solubility of transition metal compounds in water becomes a primary requirement in the design and development of environmentally benign catalysts for use under biphasic conditions as well as for their biomedicine applications mostly focused as contrast agents.

\section{EXPERIMENTAL SECTION}

General Remarks. All reactions were carried out under a nitrogen atmosphere with standard Schlenck techniques. The dhprpe diphosphine and $\left[\mathrm{Et}_{4} \mathrm{~N}\right]_{2}\left[\mathrm{Mo}_{3} \mathrm{~S}_{7} \mathrm{Cl}_{6}\right]$ were prepared according to literature methods. ${ }^{32,33}$ The starting complex $\mathrm{Mo}_{3} \mathrm{~S}_{4} \mathrm{Cl}_{4}\left(\mathrm{PPh}_{3}\right)_{3}$ was prepared from $\left(\mathrm{Et}_{4} \mathrm{~N}\right)_{2}\left[\mathrm{Mo}_{3} \mathrm{~S}_{7} \mathrm{Cl}_{6}\right]$ and $\mathrm{PPh}_{3} \cdot{ }^{34,35}\left(\mathrm{H}_{7} \mathrm{O}_{3}\right)_{2}\left[\mathrm{Mo}_{6} \mathrm{Cl}_{14}\right]$ was obtained by dissolving $\mathrm{Mo}_{6} \mathrm{Cl}_{12}$ in hot concentrated $\mathrm{HCl}$ and allowing the resulting clear yellow solution to cool to give yellow needles of the product. ${ }^{36,37}$ The remaining reactants were obtained from commercial sources and used as received. Solvents for syntheses were dried and degassed by standard methods before use.

Physical Measurements. All manipulations involving free phosphine ligands were carried out under nitrogen. The complexes with phoshines, once formed, are air stable and were handled in air, showing no trace of decomposition. Elemental analyses were performed on an EA 1108 CHNS microanalyzer. ${ }^{31} \mathrm{P}\{\mathrm{H}\}$ NMR spectra were recorded on a Varian MERCURY $300 \mathrm{MHz}$ or a Varian Inova 400 instrument. Chemical shifts are referenced to external $85 \%$ $\mathrm{H}_{3} \mathrm{PO}_{4}$. Electronic absorption spectra were obtained on a PerkinElmer Lambda-19 spectrophotometer in water. Electrospray ionization mass spectra were recorded with a Q-TOF I (quadrupole-hexapoletime-of-flight) mass spectrometer with an orthogonal Z-spray electrospray interface (Micromass, Manchester, U.K.) operating at a resolution of approximately $5000(\mathrm{fwhm})$. The instrument was calibrated using a solution of $\mathrm{NaI}$ in isopropanol/water from $\mathrm{m} / \mathrm{z}$ 100 to 1900 . Sample solutions $\left(1 \times 10^{-5} \mathrm{M}\right)$ in water were introduced through a fused-silica capillary to the ESI source via syringe pump at a flow rate of $10 \mu \mathrm{L} / \mathrm{min}$. The cone voltage was set at $10 \mathrm{~V}$ unless otherwise stated to control the extent of fragmentation. Nitrogen was employed as the drying and nebulizing gas. Isotope experimental patterns were compared with theoretical patterns obtained using the MassLynx 4.0 program.

Kinetic Experiments. Kinetic experiments were carried out with an Applied Photophysics SX-17MV stopped-flow spectrometer provided with a PDA1 photodiode array (PDA) detector. All experiments were carried out at $25.0{ }^{\circ} \mathrm{C}$ by mixing an aqueous solution of $\left[\mathrm{Mo}_{3} \mathrm{~S}_{4} \mathrm{Cl}_{3}(\text { dhprpe })_{3}\right] \mathrm{Cl}$ with a previous treatment (0.05$0.10 \mathrm{M}$ ) of $\mathrm{HCl}$ or $\mathrm{KOH}$ with another solution containing an excess of the other reagents, $\mathrm{HCl}$ or $\mathrm{KOH}$. When necessary, the ionic strength was kept constant through the experiments using the required amounts of $\mathrm{KNO}_{3}, \mathrm{KCl}, \mathrm{HNO}_{3}$, or $\left(\mathrm{Et}_{4} \mathrm{~N}\right)(\mathrm{pts})\left(\mathrm{pts}^{-}=p\right.$ toluenesulfonate). Solutions of the cluster were prepared at concentrations of ca. $1 \times 10^{-4} \mathrm{M}$. In all cases, the spectral changes were measured over a wide wavelength range and analyzed with the
Specfit program. ${ }^{38}$ All data were satisfactorily fitted by a single exponential.

Synthesis. $\left[\mathrm{Mo}_{3} \mathrm{~S}_{4} \mathrm{Cl}_{3}\right.$ (dhprpe) $\left.{ }_{3}\right] \mathrm{Cl}$ ([1]Cl). $\mathrm{Mo}_{3} \mathrm{~S}_{4} \mathrm{Cl}_{4}$ $\left(\mathrm{PPh}_{3}\right)_{3}\left(\mathrm{H}_{2} \mathrm{O}\right)_{2}(0.36 \mathrm{~g}, 0.26 \mathrm{mmol})$ and $\left(\mathrm{HOCH}_{2} \mathrm{CH}_{2} \mathrm{CH}_{2}\right)_{2}$ $\mathrm{PCH}_{2} \mathrm{CH}_{2} \mathrm{P}\left(\mathrm{CH}_{2} \mathrm{CH}_{2} \mathrm{CH}_{2} \mathrm{OH}\right)_{2}$ (dhprpe) (0.26 g, $0.78 \mathrm{mmol}$ ) were stirred in $\mathrm{CH}_{3} \mathrm{CN}$ for $12 \mathrm{~h}$ under $\mathrm{N}_{2}$. A green precipitate, together with some oil, separated. Attempts to filter the product off in air led to it completely turning into a green oil. Therefore, the precipitate was washed by decantation with $\mathrm{CH}_{3} \mathrm{CN}$ to remove all $\mathrm{PPh}_{3}$ and $\mathrm{Et}_{2} \mathrm{O}$ without filtration and dried in vacuo. Yield $0.38 \mathrm{~g}$ (91\%). NMR ${ }^{31} \mathrm{P}\left\{{ }^{1} \mathrm{H}\right\}$ (ca. $0.05 \mathrm{M} \mathrm{HCl}$ in $\left.1: 1 \mathrm{H}_{2} \mathrm{O} / \mathrm{D}_{2} \mathrm{O}, 121 \mathrm{MHz}\right) \delta(\mathrm{ppm}): 32.90$ and 41.65 ppm. Anal. Calcd for $\mathrm{C}_{42} \mathrm{H}_{96} \mathrm{Cl}_{4} \mathrm{Mo}_{3} \mathrm{O}_{12} \mathrm{P}_{6} \mathrm{~S}_{4}: \mathrm{C}, 32.8 ; \mathrm{H}$, 6.3; O, 12.5. Found: C, 32.8; H, 7.8; O, 13.0.

$\left[\mathrm{Mo}_{3} \mathrm{~S}_{4} \mathrm{Cl}_{3}(\text { dhprpe })_{3}\right]_{2}\left[\mathrm{Mo}_{6} \mathrm{Cl}{ }_{14}\right] \cdot 3 \mathrm{H}_{2} \mathrm{O},\left([1]_{2}\left[\mathrm{Mo}_{6} \mathrm{Cl}{ }_{14}\right]\right) \cdot 3 \mathrm{H}_{2} \mathrm{O}$. Complex $[1] \mathrm{Cl}(48 \mathrm{mg}, 0.031 \mathrm{mmol})$ was dissolved in $1 \mathrm{~mL}$ of $\mathrm{CH}_{3} \mathrm{OH}$ to give a green solution, which was filtered and carefully mixed with a solution of $30 \mathrm{mg}$ of $\left(\mathrm{H}_{7} \mathrm{O}_{3}\right)_{2}\left[\mathrm{Mo}_{6} \mathrm{Cl}_{14}\right](0.025 \mathrm{mmol})$ in $1 \mathrm{~mL}$ of $\mathrm{CH}_{3} \mathrm{OH}$, followed by 1 drop of concentrated $\mathrm{HCl}$, and the mixture was left overnight in an open vial. A crop of green crystals, suitable for $\mathrm{X}$-ray, was isolated in quantitative yield. The complex is insoluble in common organic solvents. Anal. Calcd for $\mathrm{C}_{84} \mathrm{H}_{198} \mathrm{Cl}_{20} \mathrm{Mo}_{12} \mathrm{O}_{27} \mathrm{P}_{12} \mathrm{~S}_{8}$ : C, 24.4; H, 4.8; S, 6.2. Found: C, 24.0; H, 4.9; S, 6.2.

$\left[\mathrm{Mo}_{3} \mathrm{~S}_{4}(\text { dhprpe-H) })_{3}\right] \mathrm{PF}_{6} \cdot 5 \mathrm{H}_{2} \mathrm{O}$, $\left([2] \mathrm{PF}_{6}\right) \cdot 5 \mathrm{H}_{2} \mathrm{O}$. Complex $[\mathbf{1}] \mathrm{Cl}(48$ $\mathrm{mg}, 0.031 \mathrm{mmol}$ ) was dissolved in $2 \mathrm{~mL}$ of $\mathrm{CH}_{3} \mathrm{OH}$. The solution was filtered and carefully mixed with a solution of $300 \mathrm{mg}$ of $\mathrm{KPF}_{6}$ in $5 \mathrm{~mL}$ of $\mathrm{CH}_{3} \mathrm{OH}$, followed by addition of a few drops of $\mathrm{Et}_{3} \mathrm{~N}$ until the initial green color of the solution becomes brown. The solution was left in an open vial. A crop of brown crystals was obtained, suitable for $\mathrm{X}$-ray diffraction. Yield $30 \mathrm{mg}(63 \%)$. NMR ${ }^{31} \mathrm{P}\left\{{ }^{1} \mathrm{H}\right\}$ (ca. $0.05 \mathrm{M}$ $\mathrm{NaOH}$ in $\left.1: 1 \mathrm{H}_{2} \mathrm{O} / \mathrm{D}_{2} \mathrm{O}, 121 \mathrm{MHz}\right) \delta(\mathrm{ppm}): 16.30$ and $45.10 \mathrm{ppm}$. Anal. Calcd for $\mathrm{C}_{42} \mathrm{H}_{103} \mathrm{~F}_{6} \mathrm{Mo}_{3} \mathrm{O}_{17} \mathrm{P}_{7} \mathrm{~S}_{4}$ : C, 31.0; H, 6.4; O, 16.7 . Found: C, 31.5; H, 6.3; O, 16.9.

X-ray Studies. Diffraction data for $[1]_{2}\left[\mathrm{Mo}_{6} \mathrm{Cl}_{14}\right] \cdot 3 \mathrm{H}_{2} \mathrm{O}$ and $[2]\left[\mathrm{PF}_{6}\right] \cdot 5 \mathrm{H}_{2} \mathrm{O}$ were collected at $170 \mathrm{~K}$ on a Agilent Supernova diffractometer equipped with an Atlas CCD detector using Mo $\mathrm{K} \alpha$ radiation $(\lambda=0.71073 \AA)$. No instrument or crystal instabilities were observed during data collection. ${ }^{39}$ Absorption corrections based on the multiscan method were applied. ${ }^{40,41}$ Structures were solved by direct methods in SHELXS-97 and refined by the full-matrix method based on $F^{2}$ with the program SHELXL-97 using the OLEX software package. ${ }^{42,43}$ Crystal data for $[\mathbf{1}]_{2}\left[\mathrm{Mo}_{6} \mathrm{Cl}_{14}\right] \cdot 3 \mathrm{H}_{2} \mathrm{O}$ : $\mathrm{C}_{84} \mathrm{H}_{198} \mathrm{Cl}_{20} \mathrm{Mo}_{12} \mathrm{O}_{27} \mathrm{P}_{12} \mathrm{~S}_{8}, M=4128.82$, trigonal, space group $P \overline{3}, a$ $=15.3298(3) \AA, b=15.3298(3) \AA, c=18.3932(4) \AA, \alpha=90^{\circ}, \beta=90^{\circ}$, $\gamma=120^{\circ}, V=3743.35(13) \AA^{3}, T=170 \mathrm{~K}, Z=1, \mu(\mathrm{Mo} \mathrm{K} \alpha) 1.622$ $\mathrm{mm}^{-1}$. Reflections collected/unique $=28605 / 6267\left(R_{\text {int }}=0.0539\right)$. Final refinement converged with $R_{1}=0.0863$ and $R_{2}=0.1497$ for all reflections, $\mathrm{GOF}=1.067, \mathrm{max} / \mathrm{min}$ residual electron density $1.55 /-$ $1.07 \mathrm{e} \cdot \AA^{-3}$. Crystal data for $[2] \mathrm{PF}_{6} \cdot 5 \mathrm{H}_{2} \mathrm{O}: \mathrm{C}_{42} \mathrm{H}_{103} \mathrm{~F}_{6} \mathrm{Mo}_{3} \mathrm{O}_{17} \mathrm{P}_{7} \mathrm{~S}_{4}, M=$ 1657.33, monoclinic, space group $C_{2}, a=26.4129(10) \AA, b=$ $15.3050(5) \AA, c=18.5707(7) \AA, \alpha=90^{\circ}, \beta=108.184(4)^{\circ}, \gamma=90^{\circ}, V$ $=7132.3(4) \AA^{3}, T=167.7 \mathrm{~K}, Z=4, \mu($ Mo $\mathrm{K} \alpha) 0.865 \mathrm{~mm}^{-1}$. Reflections collected/unique $=35148 / 11948\left(R_{\text {int }}=0.0487\right)$. Final refinement converged with $R_{1}=0.0625$ and $R_{2}=0.1491$ for all reflections, $\mathrm{GOF}=1.076, \mathrm{max} / \mathrm{min}$ residual electron density $1.24 /-$ $0.46 \mathrm{e} \cdot \AA^{-3}$.

The structure of $[\mathbf{1}]_{2}\left[\mathrm{Mo}_{6} \mathrm{Cl}_{14}\right] \cdot 3 \mathrm{H}_{2} \mathrm{O}$ was refined in the trigonal $P \overline{3}$ space group where the cluster cation lies on a 3 -fold axis. Anisotropic displacement parameters were refined for all non-H atoms. Disorder was observed on three out of the four oxygen atoms of the hydroxypropyl chain. Two oxygen atoms were refined over two positions, and the disorder on the third oxygen atom was modeled over three positions. These were all refined with a constraint to the total occupancy of one. Hydrogen atoms bonded to carbon were included at their idealized positions, except for the carbon atoms bonded to the disordered oxygen atoms, and refined as riders with isotropic displacement parameters assigned as 1.2 times the $U_{\text {eq }}$ value of the corresponding bonding partner. Hydrogen atoms bonded to oxygen were also treated in a similar way with isotropic displacement parameters assigned as 1.5 times the $U_{\text {eq }}$ value of the corresponding bonding partner. We consider as unjustified inclusion of the hydrogen 
atoms for the $\mathrm{CH}_{2}$ groups and the $\mathrm{OH}$ group disordered over three positions. After location of the clusters, two peaks on special positions remained in the difference Fourier map. These peaks were assigned to oxygen from the solvent $\mathrm{H}_{2} \mathrm{O}$ molecules and refined anisotropically. The structure of $[2]\left[\mathrm{PF}_{6}\right] \cdot 5 \mathrm{H}_{2} \mathrm{O}$ was solved in the noncentrosymmetric monoclinic $C_{2}$ space group. All non-hydrogen atom were refined anisotropically. The only nonroutine feature was the disorder of an oxygen atom in one of the hydroxyproplyl chains, which was modeled over three positions with a constraint to the total occupancy of one. As in the previous structure, the remaining peaks after location of the cluster and anion were assigned to oxygen atoms and refined anisotropically. The absolute structure parameter refined to a value of $0.43(4)$. Structural figures were drawn using Diamond. ${ }^{44}$

\section{RESULTS AND DISCUSSION}

Synthesis, Solid State, and Solution Structures of the $1^{+}$and $2^{+}$Complexes. Polymeric $\mathrm{M}_{3} \mathrm{Q}_{7} \mathrm{X}_{4 / 2} \mathrm{X}_{2}$ one-dimensional phases have been extensively used as starting materials for preparation of incomplete cuboidal clusters of formula $\left.\left[\mathrm{M}_{3} \mathrm{Q}_{4} \mathrm{X}_{3} \text { (diphosphine }\right)_{3}\right]^{+20,45}$ However, this route fails for diphosphine ligands wearing terminal hydroxo groups, and molecular precursors such as $\left[\mathrm{Mo}_{3} \mathrm{~S}_{7} \mathrm{Cl}_{6}\right]^{2-}$ had to be used for synthesis of the $\left[\mathrm{Mo}_{3} \mathrm{~S}_{4} \mathrm{Cl}_{3}(\mathrm{dhmpe})_{3}\right]^{+}$(dhmpe $=1$,2-bis (bis(hydroxymethyl)phosphino)ethane) cluster cation. ${ }^{31}$ In both cases the reaction implies reduction of the $\mathrm{M}_{3}\left(\mu_{3}-\mathrm{Q}\right)\left(\mu-\mathrm{Q}_{2}\right)_{2}$ dichalcogenide bridges to chalcogenides to form the $\mathrm{M}_{3}\left(\mu_{3}\right.$ $\mathrm{Q})(\mu-\mathrm{Q})_{3}$ cuboidal core. A more efficient strategy could be envisioned using as starting material a molecular complex that already contains the $\mathrm{M}_{3} \mathrm{Q}_{4}$ cluster unit. For synthesis of $\left.\left[\mathrm{Mo}_{3} \mathrm{~S}_{4} \mathrm{Cl}_{3} \text { (dhprpe) }\right]_{3}\right]^{+}$(dhprpe $=1,2$-bis(bis(hydroxyprophyl)phosphino)ethane) we employed the in-situ-prepared $\mathrm{Mo}_{3} \mathrm{~S}_{4} \mathrm{Cl}_{4}\left(\mathrm{PPh}_{3}\right)_{3}(\mathrm{solv})_{2}$ compound obtained by treatment of $\left[\mathrm{Mo}_{3} \mathrm{~S}_{7} \mathrm{Cl}_{6}\right]^{2-}$ with triphenylphosphine, according to eq 1 .

$$
\begin{aligned}
& {\left[\mathrm{Mo}_{3} \mathrm{~S}_{7} \mathrm{Cl}_{6}\right]^{2-}+6 \mathrm{PPh}_{3}} \\
& \quad \rightarrow \mathrm{Mo}_{3} \mathrm{~S}_{4} \mathrm{Cl}_{4}\left(\mathrm{PPh}_{3}\right)_{3}(\text { solv })_{2}+3 \mathrm{SPPh}_{3}
\end{aligned}
$$

Reaction of $\mathrm{Mo}_{3} \mathrm{~S}_{4} \mathrm{Cl}_{4}\left(\mathrm{PPh}_{3}\right)_{3}(\text { solv })_{2}$ with stoichiometric amounts of dhprpe, represented in eq 2, in acetonitrile produces a green precipitate characterized as $\left.\left[\mathrm{Mo}_{3} \mathrm{~S}_{4} \mathrm{Cl}_{3} \text { (dhprpe) }\right)_{3}\right] \mathrm{Cl}$ in $91 \%$ yield

$$
\begin{aligned}
& \mathrm{Mo}_{3} \mathrm{~S}_{4} \mathrm{Cl}_{4}\left(\mathrm{PPh}_{3}\right)_{3}(\text { solv })_{2}+3 \text { dhprpe } \\
& \quad \rightarrow\left[\mathrm{Mo}_{3} \mathrm{~S}_{4} \mathrm{Cl}_{3}(\text { dhprpe })_{3}\right] \mathrm{Cl}+3 \mathrm{SPPh}_{3}
\end{aligned}
$$

This work illustrates the generality of this procedure to obtain $\left.\left[\mathrm{M}_{3} \mathrm{Q}_{4} \mathrm{X}_{3} \text { (diphosphine }\right)_{3}\right]^{+}$complexes containing different diphosphines decorated with functional groups and was first applied by us for isolation of $\mathrm{Mo}_{3} \mathrm{Q}_{4}(\mathrm{Q}=\mathrm{S}$, Se $)$ complexes coordinated to TTF (tetrathiafulvalene) functionalized diphosphines. ${ }^{46}$ Single crystals of X-ray quality were obtained from methanolic $\mathrm{HCl}$ solutions of $[1] \mathrm{Cl}$ in the presence of a bulky counterion, $\left[\mathrm{Mo}_{6} \mathrm{Cl}_{14}\right]^{2-}$, by slow evaporation. The molecular structure of $\mathbf{1}^{+}$is shown in Figure 1 together with a list of selected bond distances.

Complex $[1] \mathrm{Cl}$ is highly soluble in water $(0.1 \mathrm{M})$, in contrast with the limited water solubility observed for its dihydroxymethyl analog $\left(1 \times 10^{-3} \mathrm{M}\right)$. Addition of a base to aqueous or methanolic solutions of $\mathbf{1}^{+}$produces a color change from green to brown due to ring closure through the oxygen atom of the hydroxyl group to afford $\left[\mathrm{Mo}_{3} \mathrm{~S}_{4}(\text { dhprpe- } \mathrm{H})_{3}\right]^{+}\left(\mathbf{2}^{+}\right)$. The noninnocent character of the hydroxo groups in hydroxyalkyl phoshines is well documented and was already proposed in previous speciation studies on the $\left[\mathrm{Mo}_{3} \mathrm{~S}_{4} \mathrm{Cl}_{3}(\mathrm{dhmpe})_{3}\right]^{+}$

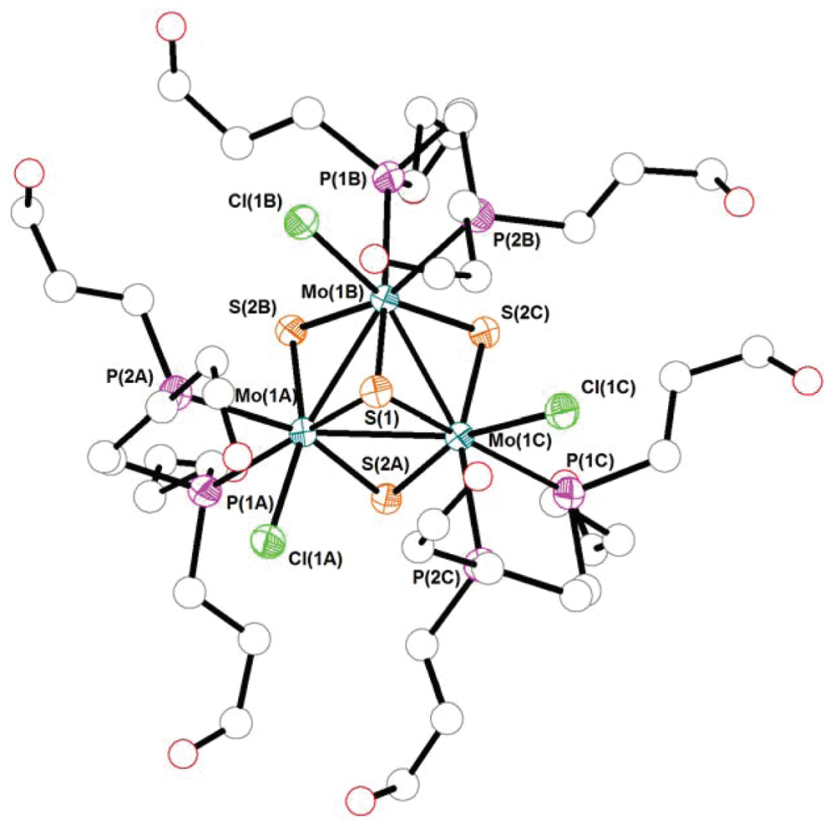

Figure 1. ORTEP representation (50\% probability ellipsoids) of the cationic cluster $\mathbf{1}^{+}$with atom-numbering scheme. Disordered oxygen atoms are omitted for clarity. Selected bond lengths $(\AA)$ : Mo-Mo $2.7950(8), \mathrm{Mo}-\left(\mu_{3}-(\mathrm{S}(1)) 2.3606(18), \mathrm{Mo}-\left(\mu-(\mathrm{S})_{\text {trans-P }}\right) 2.3202(15)\right.$, $\mathrm{Mo}-\left(\mu-(\mathrm{S})_{\text {trans-Cl }}\right) 2.2800(15), \mathrm{Mo}-\mathrm{Cl} 2.4910(15)$, Mo-P(1) 2.5619(16), Mo-P(2) 2.6299(17).

(dhmpe $=1,2$-bis ((bis)hydroxymethyl)phosphino)ethane) complex, although all attempts to grow single crystals in this last case were unsuccessful. ${ }^{18,31,32}$ For the $2^{+}$cation, single crystals were obtained as $[2] \mathrm{PF}_{6}$ salts by slow evaporation of aqueous solutions containing triethylamine. The molecular structure of $\mathbf{2}^{+}$is shown in Figure 2 together with a list of selected bond distances. Bond distances in complexes $\mathbf{1}^{+}$and $2^{+}$

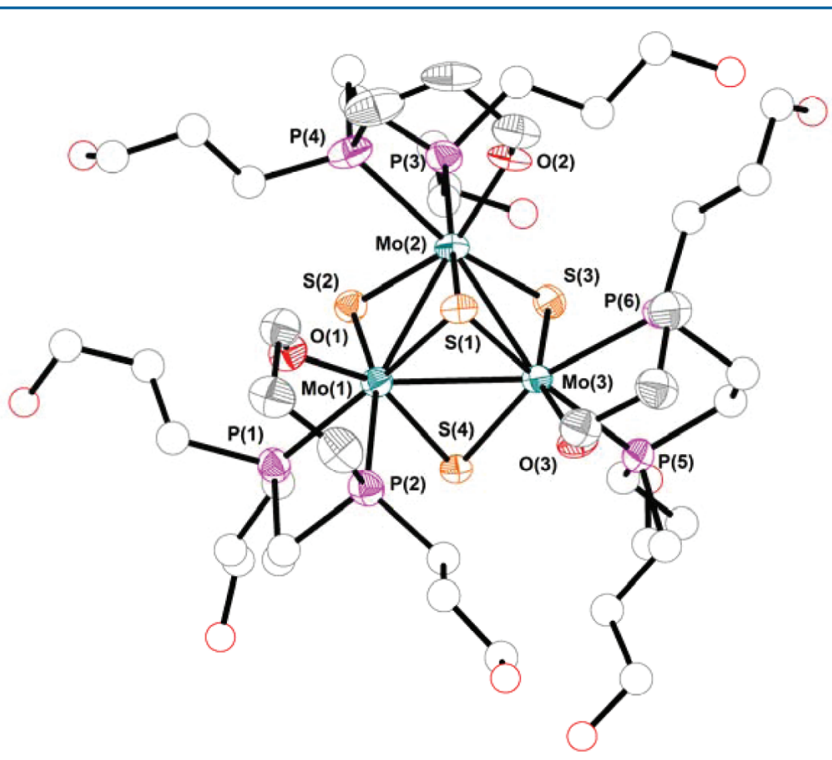

Figure 2. ORTEP representation (50\% probability ellipsoids) of the cationic cluster $2^{+}$with atom-numbering scheme. Disordered oxygen atoms are omitted for clarity. Selected bond averaged lengths $(\AA)$ : Mo-Mo 2.8036[9], Mo- $\left(\mu_{3}-(\mathrm{S}(1)) 2.3810[19], \mathrm{Mo}-\left(\mu-(\mathrm{S})_{\text {trans-P }}\right)\right.$ $2.334[2], \mathrm{Mo}-\left(\mu-(\mathrm{S})_{\text {trans-O }}\right) 2.332[2], \mathrm{Mo}-\mathrm{O} 2.018[5]$, Mo$\left((\mathrm{P})_{\text {trans }-\mu 3-\mathrm{S}(1)}\right) 2.520[2], \mathrm{Mo}-\left((\mathrm{P})_{\text {trans }-\mu 2-(\mathrm{S})}\right) 2.580[2]$. 
c)

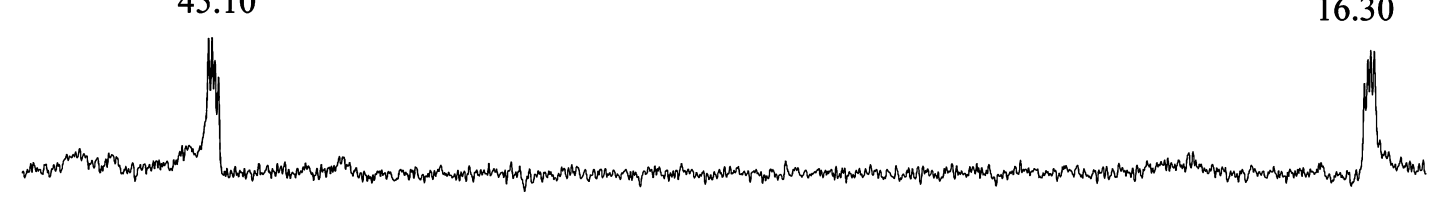

41.65

32.90

b)

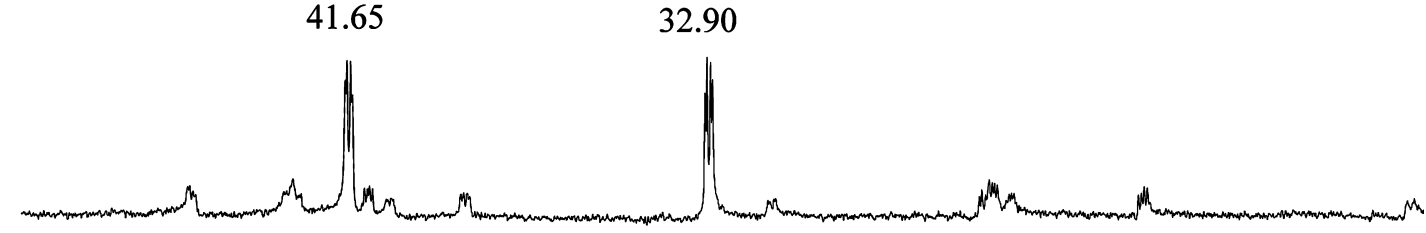
41.65
32,90

a)
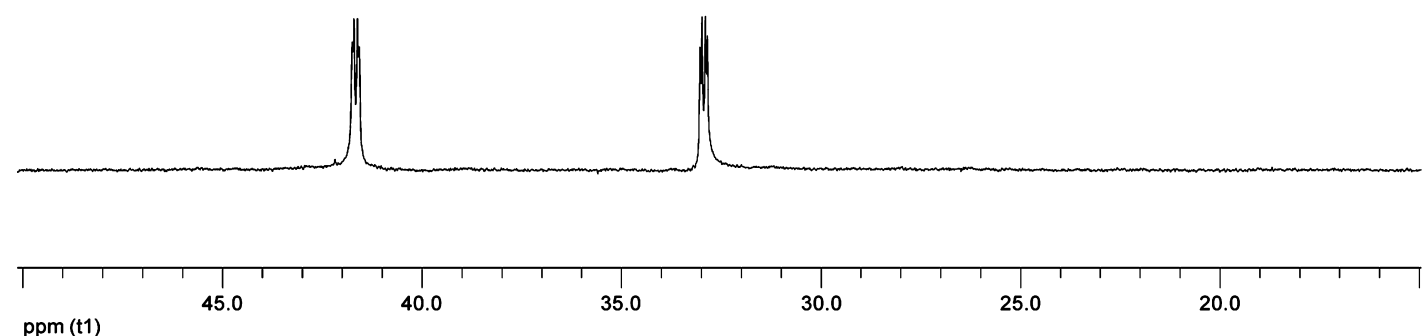

ppm (t1)

Figure 3. ${ }^{31} \mathrm{P}\left\{{ }^{1} \mathrm{H}\right\}$ NMR spectra of $\mathbf{1}^{+}$in $\mathrm{HCl}$ (aq) $0.05 \mathrm{M}$ (a) in $\mathrm{H}_{2} \mathrm{O}$ (b) and of $\mathbf{2}^{+}$in $\mathrm{NaOH}$ (aq) $0.05 \mathrm{M}$.

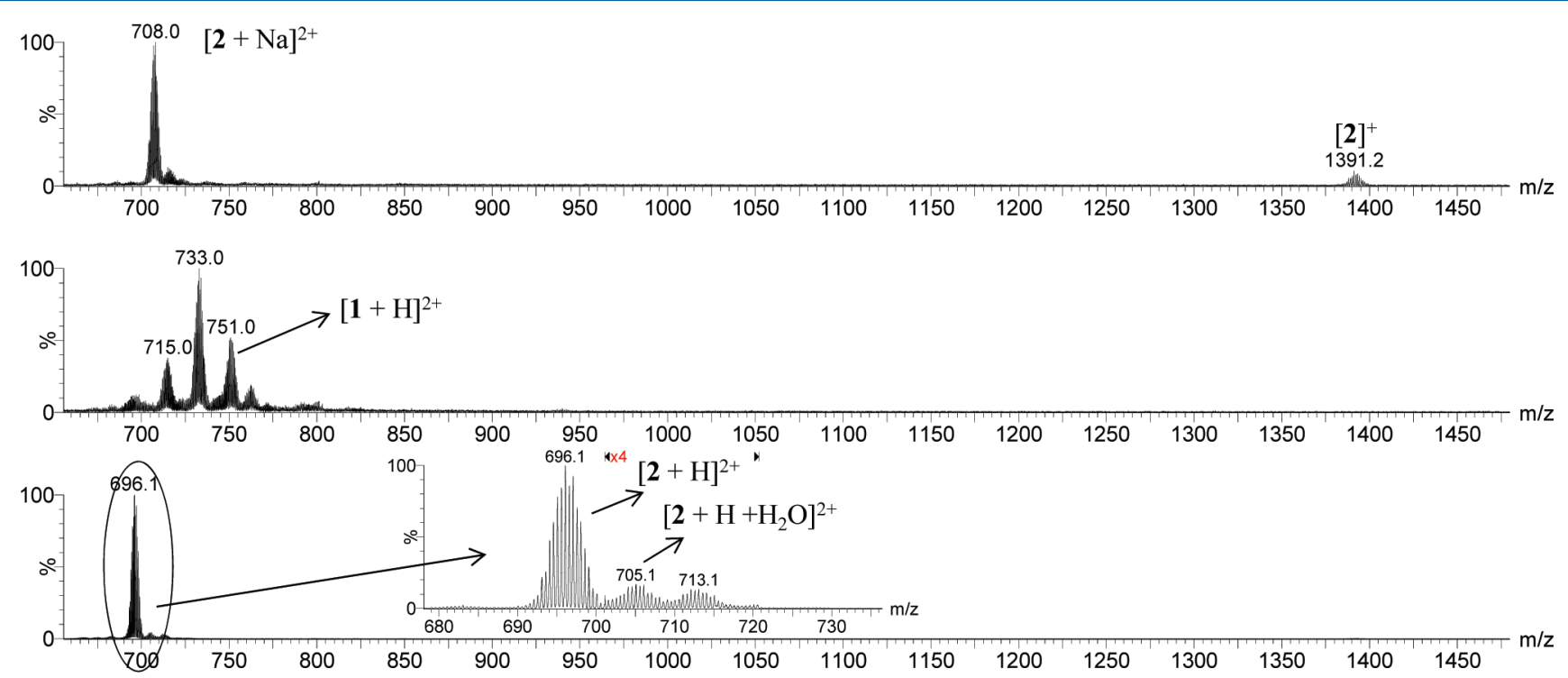

Figure 4. ESI-MS spectra of $1 \times 10^{-5} \mathrm{M}$ solutions of compound $\mathbf{1}[\mathrm{Cl}]$ at $\mathrm{Uc}=10 \mathrm{~V}$ in $\mathrm{H}_{2} \mathrm{O}$ (bottom) and in the presence of aqueous $0.001 \mathrm{M} \mathrm{HCl}$ (middle) and $0.001 \mathrm{M} \mathrm{NaOH}$ (top). In these experiments the added amount of $\mathrm{HCl}$ or $\mathrm{NaOH}$ was limited due to the ionization inhibition effects.

compare well with those observed for other diphosphino $\mathrm{Mo}_{3} \mathrm{~S}_{4}$ trinuclear clusters. ${ }^{20}$ The metal-oxygen bond length in $2^{+}$of $2.017 \AA$ agrees with the formulation of an alkoxo group coordinated to molybdenum. Due to the similar trans influences of the phosphorus and oxygen atoms, the Mo- $(\mu$ $S)$ distances in $\mathbf{2}^{+}$are similar while in $\mathbf{1}^{+}$there is asymmetry in the molybdenum-bridging sulfides bond lenths with the Mo( $\mu$-S) distance trans to phosphorus being $0.04 \AA$ longer.

${ }^{31} \mathrm{P}$ NMR and ESI-MS Studies on Speciation of $1^{+}$and $\mathbf{2}^{+}$in Aqueous Solution. The ${ }^{31} \mathrm{P}\left\{{ }^{1} \mathrm{H}\right\}$ NMR spectrum of $\mathbf{1}^{+}$ in aqueous $\mathrm{HCl}$ solutions shows two signals at 41.65 and 32.90 ppm (see Figure 3a) corresponding to two kinds of phosphorus nuclei, located above and below the plane defined by the three metal atoms, in agreement with the solid state structure. The ${ }^{31} \mathrm{P}\left\{{ }^{1} \mathrm{H}\right\}$ NMR spectrum of $\mathbf{1}^{+}$in aqueous solution (see Figure $3 \mathrm{~b}$ ) shows, in addition to the signals attributed to $\mathbf{1}^{+}$, a series of less intense signals with the characteristic multiplicity of diphosphine coordinated to the $\mathrm{Mo}_{3} \mathrm{~S}_{4}$ core. This relatively crowded ${ }^{31} \mathrm{P}\left\{{ }^{1} \mathrm{H}\right\}$ NMR spectrum is due to partial substitution of one (or two) out of the three Mo sites that produces a symmetry lowering from $C_{3}$ to $C_{1}$ symmetry, and consequently, up to six phosphorus resonances for each species are observed. Noticeably, ${ }^{31} \mathrm{P}\left\{{ }^{1} \mathrm{H}\right\}$ NMR spectra are significantly affected by cluster concentration in water. For example, on going from $5 \times$ 
$10^{-3}$ to $1 \times 10^{-3} \mathrm{M}$ solutions of $1^{+}$, the intensity of the genuine signals assigned to $\mathbf{1}^{+}$(41.65 and $32.90 \mathrm{ppm}$ ) decreases relative to the new appearing signals. This experimental evidence indicates a coexistence of species in solution containing different ligands at the Mo sites occupied by chlorine in the starting complex, ${ }^{47-50}$ which markedly depends on concentration. Similarly, the spectrum of $\mathbf{2}^{+}$in basic solutions also shows two signals at 16.30 and $45.10 \mathrm{ppm}$ (see Figure 3c), also consistent with its solid state structure determined in the previous section. When the spectrum of $2^{+}$is recorded in water without addition of base, additional species are formed as judged by the number of ${ }^{31} \mathrm{P}$ NMR signals. This experimental evidence suggests that the integrity of $\mathbf{1}^{+}$and $2^{+}$in solution is affected by the amount of $\mathrm{H}_{2} \mathrm{O}$ relative to $\mathbf{1}^{+}$and $2^{+}$, and for this reason, detailed kinetic investigations (see below) were carried out in the presence of added $\mathrm{HCl}$ or $\mathrm{KOH}$ at a given concentration $(0.025$ or $0.050 \mathrm{M})$ to force initial complete conversion to $\mathbf{1}^{+}$or $2^{+}$, respectively.

We also investigated the aqueous speciation of $\mathbf{1}^{+}$and $\mathbf{2}^{+}$and its reactivity using ESI-MS. For the family of $\left.\left[\mathrm{Mo}_{3} \mathrm{~S}_{4} \mathrm{Cl}_{3} \text { (diphos) }\right]_{3}\right]^{+}$complexes bearing diphosphine ligands, this technique has been particularly useful and typically ESI mass spectra of acetonitrile solutions yield the intact $[\mathrm{M}]^{+}$ cation as base peak. ${ }^{51}$ It has also been very useful in the study of related $\mathrm{Mo}_{3} \mathrm{~S}_{4}$ complexes bearing hydroxyalkyldiphosphines in aqueous media where the dominant presence of doubly charged species is typically observed, which differs from typical ESI mass spectra of $\mathrm{Mo}_{3} \mathrm{~S}_{4}$ clusters in organic media. ${ }^{31}$ For example, aqueous solutions of the $\left[\mathrm{Mo}_{3} \mathrm{~S}_{4} \mathrm{Cl}_{3}(\mathrm{dhmpe})_{3}\right]^{+}$cation were identified as $\left[\mathrm{Mo}_{3} \mathrm{~S}_{4}(\mathrm{dhmpe})(\mathrm{dhmpe}-\mathrm{H})_{2}\right]^{2+}$ based on ESI-MS, ${ }^{31} \mathrm{P} \mathrm{NMR}$, and stopped flow kinetic experiments. ${ }^{31}$ In the present case, the ESI mass spectrum of aqueous $1 \times 10^{-5} \mathrm{M}$ of [1] Cl revealed a prominent peak centered at $\mathrm{m} / \mathrm{z} 696.1$ attributed to the chlorine-free $\left[\mathrm{Mo}_{3} \mathrm{~S}_{4}(\text { dhprpe })(\text { dhprpe-H })_{2}\right]^{2+}$ dication (see Figure 4) on the basis of the $\mathrm{m} / \mathrm{z}$ value and its characteristic isotopic pattern. A barely detected species at $\mathrm{m} / \mathrm{z}$ 705.1 is also observed assigned to the $\left[\mathrm{Mo}_{3} \mathrm{~S}_{4}\right.$ (dhprpe)(dhprpe$\left.\mathrm{H})_{2}\left(\mathrm{H}_{2} \mathrm{O}\right)\right]^{2+}$ dication (inset in Figure 4 (bottom) has been 4 fold increased in the $m / z 700-720$ range to highlight this peak). The presence of intact $\mathbf{1}^{+}$was not observed at all (neither as a singly nor as a doubly charged peak). It is also interesting to note that a formulation as $\left[\mathrm{Mo}_{3} \mathrm{~S}_{4}\right.$ (dhprpe)(dhprpe- $\left.\mathrm{H})_{2}\right]^{2+}(\mathrm{m} / z$ 696.1) implies a vacant coordination site for one of the metal centers, although it probably results from dissociation of a coordinated water molecule from $\left[\mathrm{Mo}_{3} \mathrm{~S}_{4} \text { (dhprpe) }(\text { dhprpe- } \mathrm{H})_{2}\left(\mathrm{H}_{2} \mathrm{O}\right)\right]^{2+}(\mathrm{m} / z$ 705.1, see inset in Figure 4) upon the ESI conditions. Hence, we hypothesize the formulation of $\left[\mathrm{Mo}_{3} \mathrm{~S}_{4}(\text { dhprpe })(\text { dhprpe- } \mathrm{H})_{2}\right]^{2+}$ or $\left[\mathrm{Mo}_{3} \mathrm{~S}_{4} \text { (dhprpe) }(\text { dhprpe- } \mathrm{H})_{2}\left(\mathrm{H}_{2} \mathrm{O}\right)\right]^{2+}$ for aqueous solutions of $\mathrm{1}^{+}$. Precedent for this formulation follows from earlier investigations on the homologue dhmpe cluster. ${ }^{31}$ Despite the inherent differences between ${ }^{31} \mathrm{P}\left\{{ }^{1} \mathrm{H}\right\} \quad \mathrm{NMR}$ and ESI-MS techniques related to the concentration interval, both techniques evidence that aqueous speciation of $[\mathbf{1}] \mathrm{Cl}$ solutions is dominated by chlorine-free species as solutions are diluted in water. The all-chlorine $\mathbf{1}^{+}$complex can be reversibly regenerated as judged the ESI mass spectrum of $0.001 \mathrm{M}$ $\mathrm{HCl}$ aqueous $1 \times 10^{-5} \mathrm{M}$ of $[1] \mathrm{Cl}$ solutions where the presence of peaks due to partial (peaks centered at $m / z=714.5$ and 733.0) and complete chlorine incorporation $\left([1+\mathrm{H}]^{2+}\right.$ peak centered at $m / z=751.0$ (see Figure 4 (top)) are observed

On the other hand, the signal at $m / z 696.1$ is also the base peak in the ESI-MS spectra of aqueous solutions of $[2] \mathrm{PF}_{6}$, although in this case that signal coexists with another one at 1391.2 that corresponds to $2^{+}$, in agreement with the NMR results. When $\mathrm{NaOH}$ solutions of $[2] \mathrm{PF}_{6}$ were investigated by ESI-MS (Figure 4 (top)), the disappearance of the peak at $\mathrm{m} / \mathrm{z}$ 696.1 was accompanied of formation of doubly and singly charged species at $m / z 708.0$ and 1391.2, respectively assigned to $[2+\mathrm{Na}]^{2+}$ and $\mathbf{2}^{+}$. Observation of a signal corresponding to a $\left[\mathrm{Mo}_{3} \mathrm{~S}_{4}\right.$ (dhprpe $\left.)(\text { dhprpe-H })_{2}\right]^{2+}$ species for solutions of both $\mathbf{1}^{+}$and $2^{+}$suggests that this kind of species or the related $\left[\mathrm{Mo}_{3} \mathrm{~S}_{4}(\text { dhprpe })(\text { dhprpe- } \mathrm{H})_{2}\left(\mathrm{H}_{2} \mathrm{O}\right)\right]^{2+}$ can play a role in the solution chemistry of these clusters.

Reactivity of $2^{+}$with $\mathrm{HCl}$ : Chelate Ring Opening and Chloride Coordination. Despite the complexity of the system, the behavior of the dhprpe cluster in solution is simpler than that of the related dhmpe complex, for which even more complex mixtures of species are formed. In particular, the absence of hydroxo complexes represents a major simplification and makes the system interesting for providing kinetic information about the closure and opening of chelate rings without interference from additional processes. As aqueous solutions of $[1] \mathrm{PF}_{6}$ contain a mixture of species, kinetic studies were carried out with solutions containing added $\mathrm{HCl}$ or $\mathrm{KOH}$ to force complete conversion to $\mathbf{1}^{+}$or $2^{+}$. In this way, the kinetics of the reaction in Scheme 1 could be studied in both

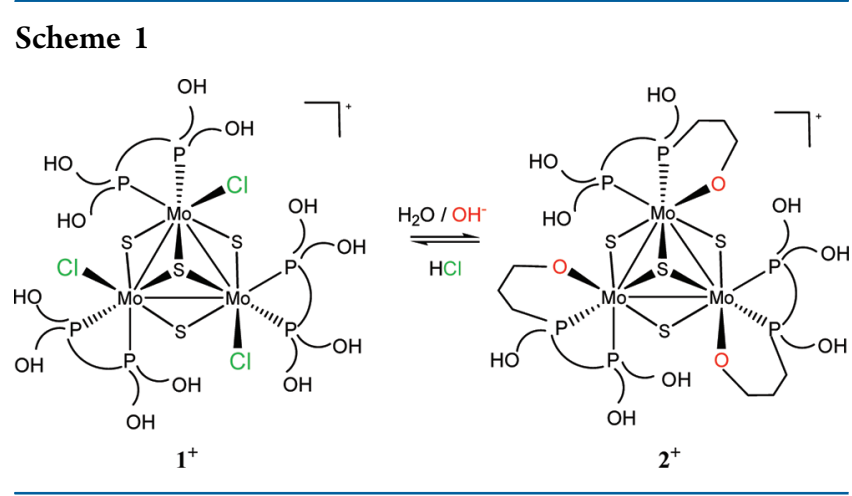

directions, i.e., chloride substitution with chelate ring closure and ring opening with chloride coordination. For simplicity, the results for conversion of $\mathbf{2}^{+}$to $\mathbf{1}^{+}$will be discussed first.

Formation of $\mathbf{1}^{+}$by reaction of $2^{+}$with an excess of $\mathrm{HCl}$ in aqueous solution occurs with spectral changes as illustrated in Figure 5, which can be satisfactorily fitted by a single exponential to yield $k_{\text {obs }}$ values that change linearly with the concentration of acid (eq 3 with $k_{\mathrm{HCl}}=85 \pm 2 \mathrm{M}^{-1} \mathrm{~s}^{-1}$, see Figure 6). As NMR spectra indicate complete conversion of $2^{+}$ to $\mathbf{1}^{+}$under those conditions, the single resolved kinetic step corresponds to reaction at the three metal centers with statistically controlled kinetics, as frequently observed in reactions of this type of cluster. ${ }^{19,52-54}$ This implies that the rates of reaction at the three metal centers are in the 3:2:1 statistical ratio, the three centers also behave as independent chromophores, and the expected three-phase kinetics is simplified to a single exponential with a rate constant that corresponds to reaction at the third center. ${ }^{55}$ For simplicity, in the discussion below only reaction at a single metal center will be considered, although operation of statistical kinetics indicates that each kinetic step is repeated at the three centers with rate constants $3 k_{\mathrm{HCl}}, 2 k_{\mathrm{HCl}}$, and $k_{\mathrm{HCl}}$.

$$
k_{\mathrm{obs}}=k_{\mathrm{HCl}}[\mathrm{HCl}]
$$




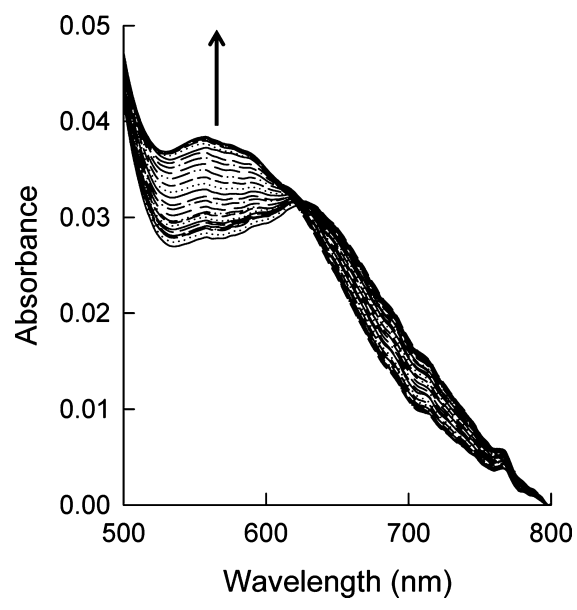

Figure 5. Typical spectral changes for reaction of $2^{+}$with $\mathrm{HCl}$ to form $1^{+}\left(T=25.0^{\circ} \mathrm{C}\right.$, cluster concentration $=1.0 \times 10^{-4} \mathrm{M}$, reaction carried out with a starting concentration of $\mathrm{KOH}$ of $0.025 \mathrm{M}$ ).

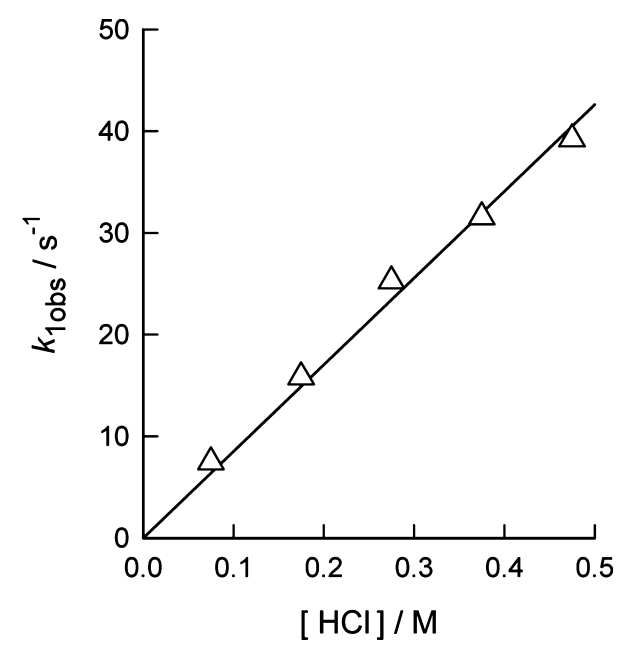

Figure 6. Plot of the dependence of $[\mathrm{HCl}]$ on the rate constants for reaction of $\mathbf{2}^{+}$with hydrochloric acid in aqueous solution.

Because there are no $\mathrm{HCl}$ molecules under the experimental conditions used, the dependence in eq 3 can arise from a dependence on $\left[\mathrm{H}^{+}\right]$or $\left[\mathrm{Cl}^{-}\right]$or even on a mixture of both of them. To solve this ambiguity, kinetic experiments were carried out with fixed concentrations of one of these ions $\left(\mathrm{H}^{+}\right.$or $\left.\mathrm{Cl}^{-}\right)$ and variable concentrations of the other. In all cases the spectral changes could be also fitted by a single exponential, and the concentration dependences are illustrated in Figures 7 and 8, which show clearly now the existence of nonzero intercepts that change with the concentration of the reagent that is fixed. As the magnitude of the spectral changes is similar for all experiments, it must be concluded that reaction goes to completion in all cases and so the nonzero intercepts cannot be ascribed to contribution from the reverse reaction in a reversible process but to parallel pathways involving ratedetermining attacks by $\mathrm{H}^{+}$and $\mathrm{Cl}^{-}$, respectively. Moreover, these results also demonstrate that the dependence in Figure 6 results from a dependence on the concentrations of both $\mathrm{H}^{+}$ and $\mathrm{Cl}^{-}$, so that all the sets of data can be fitted by eq 4 with the values of $k_{\mathrm{H}}$ and $k_{\mathrm{Cl}}$ included in Table 1 . When the experiments are carried out with an excess of $\mathrm{HCl}$, the concentration of both species is essentially the same and eq 4 simplifies to eq 3 with $k_{\mathrm{HCl}}=k_{\mathrm{H}}+k_{\mathrm{C} \text {, }}$ and actually the $k_{\mathrm{H}}+k_{\mathrm{Cl}}$

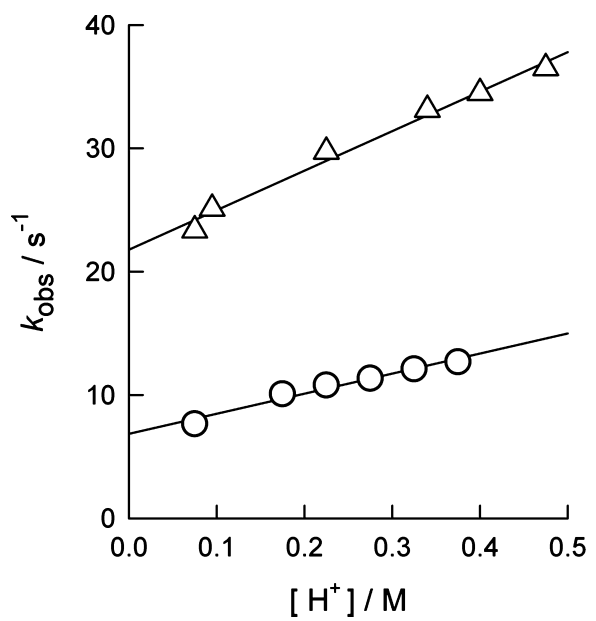

Figure 7. Plots of the rate constant dependence on $\left[\mathrm{H}^{+}\right]$for reaction of $2^{+}$with $\mathrm{H}^{+}$and $\mathrm{Cl}^{-}$in aqueous solution. Circles correspond to the reaction keeping constant the concentration of chloride at $0.10 \mathrm{M}$, while the triangles correspond to $0.50 \mathrm{M}$.

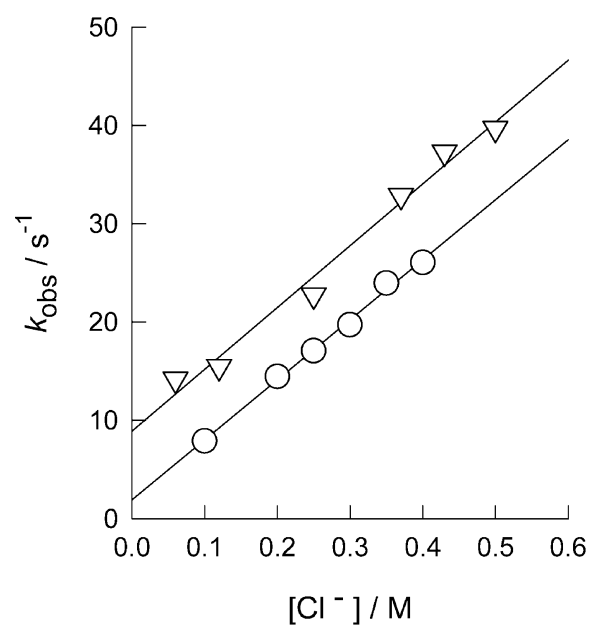

Figure 8. Plots of the rate constant dependence on $\left[\mathrm{Cl}^{-}\right]$for reaction of $2^{+}$with $\mathrm{H}^{+}$and $\mathrm{Cl}^{-}$in aqueous solution. Circles correspond to the reaction keeping constant the concentration of protons at $0.075 \mathrm{M}$, while the triangles correspond to $0.475 \mathrm{M}$.

Table 1. Summary of Resolved Rate Constants for Reaction of $2^{+}$with $\mathrm{HCl}$ To Form $1^{+}$

\begin{tabular}{ccccc}
$\begin{array}{c}\text { species with fixed } \\
\text { concentration }\end{array}$ & & $k_{\mathrm{H}}$ & $k_{\mathrm{Cl}}$ & $k_{\mathrm{H}}+k_{\mathrm{Cl}}$ \\
{$\left[\mathrm{H}^{+}\right]$} & $0.075 \mathrm{M}$ & $25 \pm 8$ & $61 \pm 2$ & $86 \pm 8$ \\
& $0.475 \mathrm{M}$ & $19 \pm 3$ & $63 \pm 4$ & $82 \pm 5$ \\
{$\left[\mathrm{Cl}^{-}\right]$} & $0.10 \mathrm{M}$ & $16 \pm 1$ & $69 \pm 4$ & $85 \pm 4$ \\
& $0.50 \mathrm{M}$ & $32 \pm 1$ & $44 \pm 1$ & $75 \pm 2$ \\
\hline
\end{tabular}

values in Table 1 are in all cases close to the value derived from experiments using $\mathrm{HCl}\left(85 \mathrm{M}^{-1} \mathrm{~s}^{-1}\right)$. Although the last entry of Table 1 deviates slightly from the other data in the table, the deviation is probably not large enough to justify introduction of an additional pathway. The values of $k_{\mathrm{H}}$ and $k_{\mathrm{Cl}}$ derived from the four sets of experiments in Table 1 are $k_{\mathrm{H}}=23 \pm 3 \mathrm{M}^{-1} \mathrm{~s}^{-1}$ and $k_{\mathrm{Cl}}=59 \pm 4 \mathrm{M}^{-1} \mathrm{~s}^{-1}$.

$$
k_{\mathrm{obs}}=k_{\mathrm{H}}\left[\mathrm{H}^{+}\right]+k_{\mathrm{Cl}}\left[\mathrm{Cl}^{-}\right]
$$


The whole set of kinetic data for this reaction can be explained with the mechanism in eqs 5-9, which consists of two parallel pathways in which the order of the attacks by $\mathrm{H}^{+}$ and $\mathrm{Cl}^{-}$are interchanged. As the observed rate constants refer to reaction at the third metal center, $\mathbf{1}^{+}$and $2^{+}$are replaced in the equations by $\mathbf{1}_{\mathrm{M} 3}{ }^{+}$and $2_{\mathrm{M} 3}{ }^{+}$, which correspond to the intermediates formed after reaction at two of the three metal centers. Thus, to complete the description of the whole process eqs 5-9 would be preceded by similar reactions occurring at the other two metal centers. This mechanism justifies the experimental results in eq 4 if the equilibrium leading to intermediate $\mathrm{I}_{0}{ }^{2+}$ is considered to be displaced to the left-hand side, so that $k_{\mathrm{H}}$ corresponds to $k_{0} K_{\mathrm{H}}$.

$$
\begin{aligned}
& \mathbf{2}_{\mathrm{M} 3}{ }^{+}+\mathrm{H}^{+} \rightleftarrows \mathrm{I}_{0}{ }^{2+} K_{\mathrm{H}} \\
& \mathrm{I}_{0}{ }^{2+} \rightarrow \mathrm{I}_{1}{ }^{2+} ; k_{0} \\
& \mathrm{I}_{1}{ }^{2+}+\mathrm{Cl}^{-} \rightarrow \mathbf{1}_{\mathrm{M} 3}{ }^{+} ; \text {fast } \\
& \mathbf{2}_{\mathrm{M} 3}{ }^{+}+\mathrm{Cl}^{-} \rightarrow \mathrm{I}_{2} ; k_{\mathrm{Cl}} \\
& \mathrm{I}_{2}+\mathrm{H}^{+} \rightarrow \mathbf{1}_{\mathrm{M} 3}{ }^{+} ; \text {fast }
\end{aligned}
$$

With regard to the nature of the intermediates, as $\mathrm{I}_{0}^{2+}$ results from rapid protonation of the coordinated alkoxo group, it is reasonable to assume it contains a coordinated $\mathrm{Pr}-\mathrm{OH}$ group, thus adopting a structure similar to that found by Tyler and coworkers ${ }^{18}$ for an iron complex with the same diphosphine. In the next step, rate-determining attack by a water molecule would lead to formation of an aqua complex $\left(\mathrm{I}_{1}{ }^{2+}\right)$ that would undergo rapid substitution of water by $\mathrm{Cl}^{-}$to complete the reaction. Although a simpler mechanism involving direct formation of intermediate $\mathrm{I}_{1}{ }^{2+}$ is also possible, the rapid preequilibrium in eq 5 has been introduced to avoid protonation being the rate-determining step. On the other hand, the $k_{\mathrm{Cl}}$ pathway starts with $\mathrm{Cl}^{-}$attack and leads to an intermediate $\mathrm{I}_{2}$ that must contain coordinated $\mathrm{Cl}^{-}$. If chloride coordination occurs with concerted opening of the chelate ring with the Pr$\mathrm{O}^{-}$group, $\mathrm{I}_{2}$ would contain an uncoordinated $\mathrm{Pr}-\mathrm{O}^{-}$that would be rapidly attacked by $\mathrm{H}^{+}$to form $\mathrm{1}_{\mathrm{M} 3}{ }^{+}$. An alternative possibility is that $\mathrm{I}_{2}$ contains both coordinated $\mathrm{Cl}^{-}$and $\mathrm{Pr}-\mathrm{O}^{-}$, i.e., the coordination number about the metal center is increased. The occurrence of associative substitutions with reorganization of the cluster core to accommodate the excess of electron density has been recently proposed for reactions of this kind of cluster. ${ }^{48,53}$

Reaction of $1^{+}$with Base: Chloride Substitution and Chelate Ring Closure. The spectral changes for reaction of $\mathbf{1}^{+}$ with base to form $2^{+}$can be also fitted satisfactorily by a single exponential, in agreement again with operation of statistical kinetics. Figure 9 illustrates the linear dependence of the observed rate constants with the concentration of base observed in three series of experiments using different concentrations of chloride. The data in Figure 9 were obtained from experiments with the ionic strength maintained by adding $p$-toluenesulfonate, but similar results were obtained using nitrate, although in the latter case the data show a larger dispersion (see Supporting Information). The linear dependence is represented by eq 10 , with $a$ and $b$ values independent of the chloride concentration, so that the overall fit of all the three set of data in Figure 9 leads to $a=0.09 \pm 0.01 \mathrm{~s}^{-1}$ and $b=$ $0.36 \pm 0.02 \mathrm{M}^{-1} \mathrm{~s}^{-1}$. The amplitude of the spectral changes is independent of the base concentration, and so the $a$ and $b$

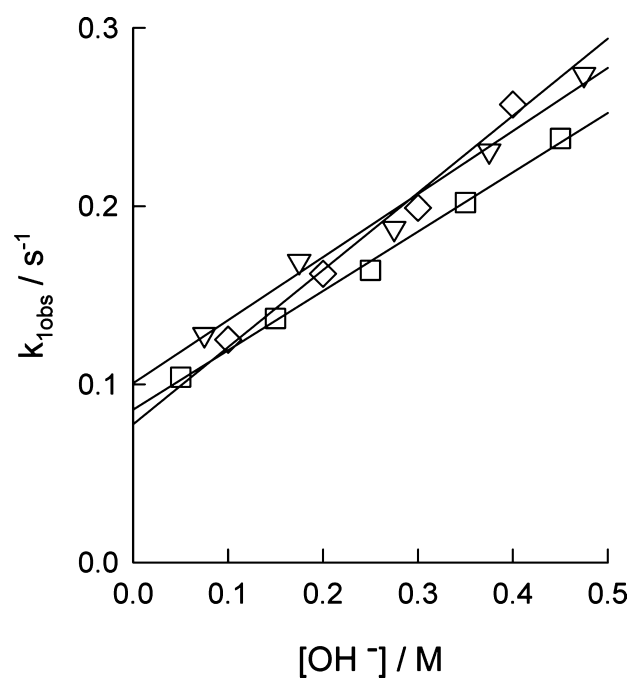

Figure 9. Plots showing the $\left[\mathrm{OH}^{-}\right]$dependence of the observed rate constant for reaction of $1^{+}$with base to form $2^{+}$. Data correspond to three sets of experiments with starting solutions containing different concentrations of $\mathrm{HCl}(0.025,0.050$, and $0.100 \mathrm{M}$; triangles, squares, and diamonds, respectively), and the ionic strength was maintained by adding the required amount of $\left(\mathrm{Et}_{4} \mathrm{~N}\right)(\mathrm{pts})$.

terms must be assigned to two parallel pathways leading to the reaction product and not to contribution of the reverse reaction.

$$
k_{\mathrm{obs}}=a+b\left[\mathrm{OH}^{-}\right]
$$

The rate law in eq 10 can be explained with the mechanism in eqs $11-15$, which use the same nomenclature as eqs 5-9 for microscopic reversibility reasons and to facilitate analysis of the reaction paths operating in both directions. Conversion to the final product occurs through two parallel pathways involving $\mathrm{H}_{2} \mathrm{O}$ and $\mathrm{OH}^{-}$attacks, respectively. However, to avoid proton transfer being the rate-determining step, $\mathrm{OH}^{-}$attack is considered to be a rapid pre-equilibrium, the resulting intermediate evolving to the final product in the next step. The rate law for this mechanism is given by eq 16 , which is equivalent to eq 10 with $a=k_{\mathrm{H} 2 \mathrm{O}}$ and $b=K_{\mathrm{OH}} \times k_{2 \mathrm{OH}}$ if the equilibrium in eq 14 is considered to be displaced to the lefthand side.

$$
\begin{aligned}
& \mathbf{1}_{\mathrm{M3}}{ }^{+}+\mathrm{H}_{2} \mathrm{O} \rightarrow \mathrm{I}_{1}^{2+}+\mathrm{Cl}^{-} ; k_{\mathrm{H} 2 \mathrm{O}} \\
& \mathrm{I}^{2+} \rightarrow \mathrm{I}_{0}{ }^{2+} ; \text { fast } \\
& \mathrm{I}^{2+}+\mathrm{OH}^{-} \rightarrow \mathbf{2}_{\mathrm{M} 3}{ }^{+} ; \text {fast } \\
& \mathbf{1}_{\mathrm{M}^{+}}{ }^{+}+\mathrm{OH}^{-} \rightleftarrows \mathrm{I}_{2} ; K_{\mathrm{OH}} \\
& \mathrm{I}_{2} \rightarrow \mathbf{2}_{\mathrm{M3}}{ }^{+}+\mathrm{Cl}^{-} ; k_{2 \mathrm{OH}} \\
& k_{\mathrm{obs}}=\frac{k_{\mathrm{H} 2 \mathrm{O}}+K_{\mathrm{OH}} k_{2 \mathrm{OH}}\left[\mathrm{OH}^{-}\right]}{1+K_{\mathrm{OH}}\left[\mathrm{OH}^{-}\right]}
\end{aligned}
$$

The mechanistic conclusions are summarized in Figure 10, where for simplicity only one of the metal centers is considered again. The reaction goes through two parallel pathways, one of them involving subsequent conversion of a $\mathrm{M}-\mathrm{Cl}$ species to species containing $\mathrm{M}-\mathrm{OH}_{2}, \mathrm{M}-\mathrm{O}(\mathrm{H})-\mathrm{Pr}$, and $\mathrm{M}-\mathrm{O}-\mathrm{Pr}$ bonds. Although only $\mathrm{M}-\mathrm{Cl}$ and $\mathrm{M}-\mathrm{O}-\mathrm{Pr}$ accumulate in this case, the existence of species with $\mathrm{M}-\mathrm{OH}_{2}$ bonds is supported 


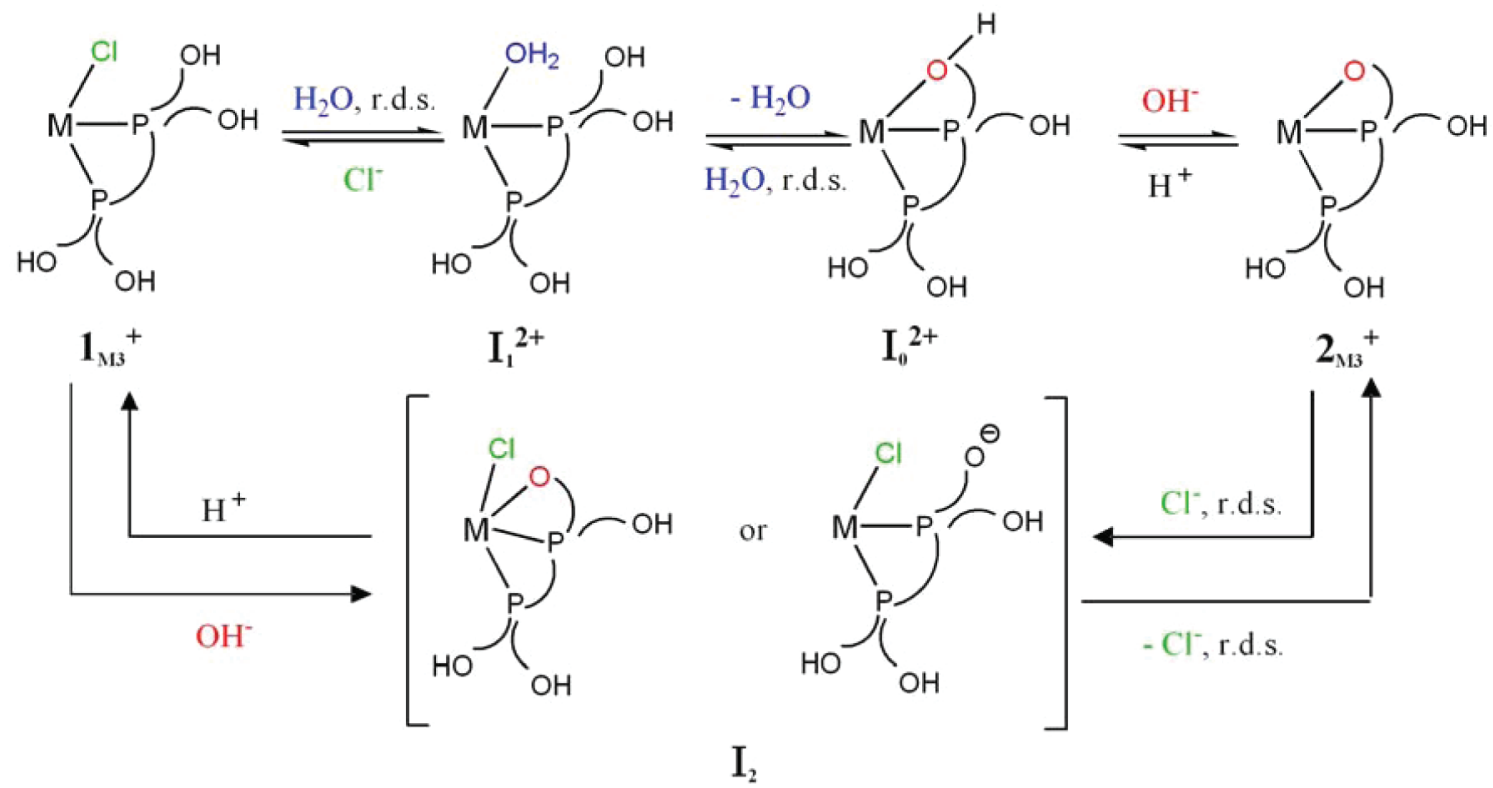

Figure 10. Mechanistic pathways for interconversion of the $\mathbf{1}^{+}$and $\mathbf{2}^{+}$clusters. For simplicity, only the reaction at a single metal center is shown, but the operation of statistical kinetics in both directions indicates that each pathway is repeated at the three metal centers with rates which are in a 3:2.1 ratio.

by the MS results, a species of the type $\mathrm{M}-\mathrm{O}(\mathrm{H})-\mathrm{Pr}$ has been characterized crystallographically for a mononuclear irondhprpe complex, ${ }^{18}$ and formation of $\mathrm{M}-\mathrm{O}-\mathrm{Pr}$ had been previously proposed ${ }^{56}$ and its existence now confirmed by Xray diffraction. This pathway is kinetically controlled by hydrolysis of the $\mathrm{M}-\mathrm{Cl}$ bond in one direction and hydrolysis of $\mathrm{M}-\mathrm{O}(\mathrm{H})-\mathrm{Pr}$ in the reverse. In contrast, the other pathway is kinetically controlled by chloride coordination or dissociation and involves formation of an intermediate species with coordinated chloride and a free or coordinated $\mathrm{Pr}-\mathrm{O}^{-}$group.

\section{CONCLUSION}

Coordination of the dhprpe diphosphine to the trinuclear $\mathrm{Mo}_{3} \mathrm{~S}_{4}$ cluster core has been found to lead to a water-soluble [1] Cl complex whose structure displays all the typical features of other $\mathrm{M}_{3} \mathrm{Q}_{4}$ incomplete cuboidal clusters. However, when dissolved in basic water solutions, $\mathbf{1}^{+}$yields complex $2^{+}$in which each coordinated chloride is replaced by a chelate ring formed with a $\mathrm{Pr}-\mathrm{O}^{-}$group, in agreement with Tyler's observation that chelate ring closure is more favored in dhprpe than in related diphosphines with other hydroxyalkyl groups. ${ }^{18}$ Kinetic studies indicate that the interconversion between $\mathbf{1}^{+}$and $2^{+}$ occurs in a single kinetic step without accumulation of any reaction intermediate and that two parallel pathways operate. However, some information about the nature of the intermediates can be derived from the ESI-MS results for water solutions at intermediate $\mathrm{pH}$ values in the presence of limited amounts of chloride, which support the existence of an aquo complex. According to the kinetic results, this aquo complex evolves rapidly to the chloro complex or the cluster with a chelated $\mathrm{PrO}^{-}$group when the concentration of chloride increases or the $\mathrm{pH}$ becomes high enough, so that it acts as reaction intermediate in the interconversion between $\mathbf{1}^{+}$and $2^{+}$. With regard to the rate-determining steps in the different paths in the mechanism proposed, the data suggest that chelate ring opening is kinetically controlled by $\mathrm{H}_{2} \mathrm{O}$ and $\mathrm{Cl}^{-}$attacks whereas chloride substitution is controlled by water attack or $\mathrm{Cl}^{-}$dissociation. In addition to the $\mathrm{M}-\mathrm{OH}_{2}$ complex, intermediates containing $\mathrm{M}-\mathrm{OPr}$ or $\mathrm{M}-\mathrm{O}(\mathrm{H}) \mathrm{Pr}$ bonds are also proposed to be formed under steady-state conditions. However, no evidence has been obtained on the existence of $\mathrm{M}-\mathrm{OH}$ species, which are dominant in the chemistry of the related dhmpe cluster in basic solutions. ${ }^{31}$ Thus, it appears that the size of the propyl chain favors formation of chelates to such an extent that the products resulting from ring opening with $\mathrm{H}_{2} \mathrm{O}$ or $\mathrm{OH}^{-}$coordination have a low stability. Further work with related diphosphines is in progress to obtain additional information about the behavior in aqueous solution of this kind of species.

\section{ASSOCIATED CONTENT}

\section{S Supporting Information}

Plots showing the $\left[\mathrm{OH}^{-}\right]$dependence of the observed rate constant for reaction of ${1^{+}}^{+}$with base to form $2^{+}$; X-ray crystallographic files in CIF format. This material is available free of charge via the Internet at http://pubs.acs.org.

\section{AUTHOR INFORMATION}

\section{Corresponding Author}

*Phone: +34 964728086 (R.L.); +34 956016339 (M.G.B.). Fax: +34 964728066 (R.L.); +34 956016288 (M.G.B.). Email: rosa.llusar@uji.es (R.L.); manuel.basallote@uca.es (M.G.B.).

\section{Notes}

The authors declare no competing financial interest.

\section{ACKNOWLEDGMENTS}

Financial support of the Spanish Ministerio de Economia y Competitividad (Grants CTQ2011-23157 and CTQ200914443-C02-01), Fundació Bancaixa-UJI (research project P1.1B2010-46), Generalitat Valenciana (ACOMP/2011/037 and Prometeo/2009/053), and Junta de Andalucía (Grupo FQM-137, Grant P07-FQM-02734) is gratefully acknowledged. The authors also thank the Servei Central DInstrumentació Cientifica (SCIC) of the Universitat Jaume I and the Servicios 
Centrales de Ciencia y Tecnología of the Universidad de Cádiz for providing us with the mass spectrometry, NMR, and X-ray facilities. T.B. thanks the Spanish Ministerio de Ciencia e Innovación (MICINN) for a doctoral fellowship (FPI).

\section{DEDICATION}

This paper is dedicated to the memory of our colleague and friend Prof. Purificación Escribano.

\section{REFERENCES}

(1) Herrmann, W. A.; Kohlpaintner, C. W. Angew. Chem., Int. Ed. Engl. 1993, 32, 1524.

(2) Dilworth, J. R.; Parrott, S. J. Chem. Soc. Rev. 1998, 27, 43.

(3) Blower, P. J. Transition Met. Chem. 1998, 23, 109.

(4) Pinault, N.; Bruce, D. W. Coord. Chem. Rev. 2003, 241, 1.

(5) Kothari, K. K.; Raghuraman, K.; Pillarsetty, N. K.; Hoffman, T. J.; Owen, N. K.; Katti, K. V.; Volkert, W. A. Appl. Radiat. Isot. 2003, 58, 543.

(6) Katti, K. V.; Gali, H.; Smith, C. J.; Berning, D. E. Acc. Chem. Res. 1999, 32, 9.

(7) James, B. R.; Lorenzini, F. Coord. Chem. Rev. 2010, 254, 420.

(8) Chatt, J.; Leigh, G. J.; Slade, R. M. J. Chem. Soc., Dalton Trans. 1973, 2021.

(9) Ellis, J. W.; Harrison, K. N.; Hoye, P. A. T.; Orpen, A. G.; Pringle, P. G.; Smith, M. B. Inorg. Chem. 1992, 31, 3026.

(10) Reddy, V. S.; Katti, K. V.; Barnes, C. L. Inorg. Chim. Acta 1995, 240, 367.

(11) Reddy, V. S.; Katti, K. V.; Barnes, C. L. J. Chem. Soc., Dalton Trans. 1996, 1301.

(12) Reddy, V. S.; Berning, D. E.; Katti, K. V.; Barnes, C. L.; Volkert, W. A.; Ketring, A. R. Inorg. Chem. 1996, 35, 1753.

(13) Baxley, G. T.; Miller, W. K.; Lyon, D. K.; Miller, B. E.; Nieckarz, G. F.; Weakley, T. J. R.; Tyler, D. R. Inorg. Chem. 1996, 35, 6688.

(14) Berning, D. E.; Katti, K. V.; Barnes, C. L.; Volkert, W. A.; Ketring, A. R. Inorg. Chem. 1997, 36, 2765.

(15) Berning, D. E.; Katti, K. V.; Barbour, L. J.; Volkert, W. A. Inorg. Chem. 1998, 37, 334.

(16) Driessen-Holscher, B.; Heinen, J. J. Organomet. Chem. 1998, $570,141$.

(17) Fukuoka, A.; Kosugi, W.; Morishita, F.; Hirano, M.; McCaffrey, L.; Henderson, W.; Komiya, S. Chem. Commun. 1999, 489.

(18) Miller, W. K.; Gilbertson, J. D.; Leiva-Paredes, C.; Bernatis, P. R.; Weakley, T. J. R.; Lyon, D. K.; Tyler, D. R. Inorg. Chem. 2002, 41, 5453.

(19) Hernandez-Molina, R.; Sokolov, M. N.; Sykes, A. G. Acc. Chem. Res. 2001, 34, 223.

(20) Llusar, R.; Uriel, S. Eur. J. Inorg. Chem. 2003, 1271.

(21) Fedorov, V. Y.; Mironov, Y. V.; Naumov, N. G.; Sokolov, M. N.; Fedin, V. P. Usp. Khim. 2007, 76, 571.

(22) Wakabayashi, T.; Ishii, Y.; Murata, T.; Mizobe, Y.; Hidai, M. Tetrahedron Lett. 1995, 36, 5585.

(23) Wakabayashi, T.; Ishii, Y.; Ishikawa, K.; Hidai, M. Angew. Chem., Int. Ed. Engl. 1996, 35, 2123.

(24) Takei, I.; Wakebe, Y.; Suzuki, K.; Enta, Y.; Suzuki, T.; Mizobe, Y.; Hidai, M. Organometallics 2003, 22, 4639.

(25) Takei, L.; Dohki, K.; Kobayashi, K.; Suzuki, T.; Hidai, M. Inorg. Chem. 2005, 44, 3768.

(26) Feliz, M.; Guillamon, E.; Llusar, R.; Vicent, C.; Stiriba, S. E.; Perez-Prieto, J.; Barberis, M. Chem.-Eur. J. 2006, 12, 1486.

(27) Seino, H.; Hidai, M. Chem. Sci. 2011, 2, 847.

(28) Yu, S. B.; Watson, A. D. Chem. Rev. 1999, 99, 2353.

(29) Sokolov, M. N.; Gushchin, A. L.; Naumov, D. Y.; Gerasko, O. A.; Fedin, V. P. Inorg. Chem. 2005, 44, 2431.

(30) Akashi, H.; Shibahara, T. Inorg. Chim. Acta 2000, 300, 572.

(31) Algarra, A. G.; Basallote, M. G.; Fernandez-Trujillo, M. J.; Guillamon, E.; Llusar, R.; Segarra, M. D.; Vicent, C. Inorg. Chem. 2007, 46, 7668 .
(32) Baxley, G. T.; Weakley, T. J. R.; Miller, W. K.; Lyon, D. K.; Tyler, D. R. J. Mol. Catal. A: Chem. 1997, 116, 191.

(33) Fedin, V. P.; Sokolov, M. N.; Mironov, Y. V.; Kolesov, B. A.; Tkachev, S. V.; Fedorov, V. Y. Inorg. Chim. Acta 1990, 167, 39.

(34) Cotton, F. A.; Kibala, P. A.; Matusz, M.; McCaleb, C. S.; Sandor, R. B. W. Inorg. Chem. 1989, 28, 2623.

(35) Sasaki, M.; Sakane, G.; Ouchi, T.; Shibahara, T. J. Cluster Sci. 1998, 9, 25.

(36) Cotton, F. A.; Wing, R. M.; Zimmerma, R. Inorg. Chem. 1967, 6, 11.

(37) Fedin, V. P.; Gerascko, O. A.; Fedorov, V. E.; Slovokhotov, Y. L.; Struchkov, Y. T. Izv. Sib. Otd. An. Khim. 1988, 64.

(38) Binstead, R. A.; Jung, B.; Zuberbühler, A. D. SPECFIT-32; Spectrum Software Associates: Chappel Hill, 2000.

(39) CrysAllis, version 171.35.11, release 16-05-2011; Agilent Ltd.: 2010 ; compiled May 162011.

(40) CrysAllis, version 171.35.11; Agilent Ltd.: 2010.

(41) Clark, R. C.; Reid, J. S. Acta Crystallogr., Sect. A 1995, 51, 887.

(42) Sheldrick, G. M. Acta Crystallogr., Sect. A 2008, 64, 112.

(43) Dolomanov, O. V.; Bourhis, L. J.; Gildea, R. J.; Howard, J. A. K.; Puschmann, H. J. Appl. Crystallogr. 2009, 42, 339.

(44) Cystal Impact Diamond-Crystal and Molecular Structure Visualization (2008) Crystal Impact-Brandenburg $\mathrm{K}$ and Putz $\mathrm{H}$ GbR, Postfach 1251, D-53002 Bonn.

(45) Llusar, R.; Vicent, C. In Inorganic Chemistry in Focus III; Meyer, G., Naumann, D., Wesermann, L., Eds.; WILEY-VCH: Weinheim, Germany, 2006; Chapter 7.

(46) Avarvari, N.; Kiracki, K.; Llusar, R.; Polo, V.; Sorribes, I.; Vicent, C. Inorg. Chem. 2010, 49, 1894.

(47) Basallote, M. G.; Estevan, F.; Feliz, M.; Fernandez-Trujillo, M. J.; Hoyos, D. A.; Llusar, R.; Uriel, S.; Vicent, C. Dalton Trans. 2004, 530.

(48) Basallote, M. G.; Feliz, M.; Fernandez-Trujillo, M. J.; Llusar, R.; Safont, V. S.; Uriel, S. Chem.-Eur. J. 2004, 10, 1463.

(49) Algarra, A. G.; Basallote, M. G.; Castillo, C. E.; Corao, C.; Llusar, R; Fernandez-Trujillo, M. J.; Vicent, C. Dalton Trans. 2006, 5725.

(50) Algarra, A. S. G.; Basallote, M. G.; Fernandez-Trujillo, M. J.; Llusar, R.; Safont, V. S.; Vicent, C. Inorg. Chem. 2006, 45, 5774.

(51) Guillamon, E.; Llusar, R.; Pozo, O.; Vicent, C. Int. J. Mass Spectrom. 2006, 254, 28.

(52) Hernandez-Molina, R.; Sykes, A. G. Coord. Chem. Rev. 1999, 187, 291.

(53) Algarra, A. G.; Basallote, M. G.; Feliz, M.; Fernandez-Trujillo, M. J.; Llusar, R.; Safont, V. S. Chem.-Eur. J. 2006, 12, 1413.

(54) Algarra, A. G.; Feliz, M.; Fernandez-Trujillo, M. J.; Llusar, R.; Safont, V. S.; Vicent, C.; Basallote, M. G. Chem.-Eur. J. 2009, 15, 4582.

(55) Espenson, J. H. Chemical Kinetics and Reaction Mechanism; Mc Graw-Hill: New York, 1995.

(56) Platt, A. W. G.; Pringle, P. G. J. Chem. Soc., Dalton Trans. 1989, 1193. 